\title{
NOTES
}

\section{Bacillus galactophilus Is a Later Subjective Synonym of Bacillus agri}

\author{
OSAMU SHIDA, ${ }^{1 *}$ HIROAKI TAKAGI, ${ }^{1}$ KIYOSHI KADOWAKI, ${ }^{1}$ SHIGEZO UDAKA, ${ }^{2}$ \\ AND KAZUO KOMAGATA ${ }^{3}$
}

Research Laboratory, Higeta Shoyu Co., Ltd., Choshi, Chiba $288,{ }^{1}$ Department of Applied Biological Sciences, Faculty of Agriculture, Nagoya University, Chikusa-ku, Nagoya $464,{ }^{2}$ and Department of Agricultural Chemistry, Faculty of Agriculture, Tokyo University of Agriculture, Setagaya-ku, Tokyo $156,{ }^{3}$ Japan

\begin{abstract}
We confirm that Bacillus galactophilus Takagi, Shida, Kadowaki, Komagata, and Udaka 1993 is a later subjective synonym of Bacillus agri Nakamura 1993 on the basis of chemosystematic data and DNA relatedness data.
\end{abstract}

Recently, Nakamura (4) and Takagi et al. (5) published the results of taxonomic studies of Bacillus brevis and related bacilli independently and almost simultaneously. Nakamura separated the species Bacillus agri and Bacillus centrosporus from $B$. brevis on the basis of phenotypic characteristics and DNA relatedness data (4). Bacillus migulanus, Bacillus choshinensis, Bacillus parabrevis, and Bacillus galactophilus were separated from $B$. brevis on the basis of phenotypic characteristics, chemosystematic data, and DNA relatedness data by Takagi et al. (5). However, Nakamura and Takagi et al. did not exchange and compare the type strains designated by each other. In this study, we compared strains of $B$. agri and $B$. centrosporus with strains of the four new species described by Takagi et al. on the basis of chemosystematic data and DNA relatedness data.

The organisms shown in Table 1 were cultured on T2 agar plates (6) for $24 \mathrm{~h}$ at $30^{\circ} \mathrm{C}$ and stored at room temperature. Preparation of chromosomal DNA, estimation of DNA base composition, analysis of cellular fatty acid composition and isoprenoid quinones, and immunological analysis of extracellular proteins by using the antiserum against the surface layer protein (protein HWP) of $B$. choshinensis HPD31 (1) were carried out by the methods described previously (5). DNA relatedness values were determined by using probes labeled with photobiotin (Vectra Laboratories, Inc., Burlin-

TABLE 1. DNA base compositions and levels of DNA relatedness for B. agri, B. galactophilus, B. centrosporus, B. migulanus, B. choshinensis, B. brevis, and B. parabrevis strains

\begin{tabular}{|c|c|c|c|c|c|c|c|c|}
\hline \multirow[b]{2}{*}{ Strain $^{a}$} & \multirow{2}{*}{$\begin{array}{c}\mathrm{G}+\mathrm{C} \\
\text { content } \\
(\mathrm{mol} \%)^{b}\end{array}$} & \multicolumn{7}{|c|}{$\%$ Reassociation with DNA from ${ }^{c}$ : } \\
\hline & & $\begin{array}{l}\text { B. agri NRRL } \\
\text { NRS-1219Td }\end{array}$ & $\begin{array}{l}\text { B. galactophilus } \\
\text { NRRL NRS-616 }\end{array}$ & $\begin{array}{l}\text { B. centrosporus } \\
\text { NRRL NRS-664 }\end{array}$ & $\begin{array}{l}\text { B. migulanus } \\
\text { ATCC } 9999^{\top}\end{array}$ & $\begin{array}{l}\text { B. choshinensis } \\
\text { HPD52 }^{\mathrm{T}}\end{array}$ & $\begin{array}{l}\text { B. brevis } \\
\text { JCM } 2503^{\mathrm{T}}\end{array}$ & $\begin{array}{l}\text { B. parabrevis } \\
{\text { IFO } 12334^{\mathrm{T}}}^{\text {IF }}\end{array}$ \\
\hline B. agri NRRL NRS- $1219^{\mathrm{T}}$ & 53.2 & 100 & 99 & $\mathrm{NT}^{e}$ & 18 & 22 & 19 & 20 \\
\hline B. agri NRRL NRS-874 & 52.2 & 100 & 100 & NT & NT & NT & NT & NT \\
\hline B. agri NRRL NRS-1060 & 52.1 & 74 & 87 & NT & NT & NT & NT & NT \\
\hline $\begin{array}{l}\text { B. galactophilus NRRL } \\
{\text { NRS- } 616^{\mathrm{T}}}^{\text {Nal }}\end{array}$ & 52.5 & 80 & 100 & 37 & NT & NT & NT & NT \\
\hline B. galactophilus HP037 & 52.8 & 79 & 72 & NT & NT & NT & NT & NT \\
\hline $\begin{array}{l}\text { B. centrosponis NRRL } \\
\text { NRS- } 664^{\mathrm{T}}\end{array}$ & 49.4 & NT & 42 & 100 & 43 & 31 & 21 & 20 \\
\hline B. migulanus ATCC $9999^{\mathrm{T}}$ & 43.1 & 1 & NT & 1 & 100 & NT & NT & NT \\
\hline B. choshinensis HPD52 ${ }^{\mathrm{T}}$ & 48.2 & 13 & NT & 27 & NT & 100 & NT & NT \\
\hline B. brevis JCM $2503^{\mathrm{T}}$ & 47.0 & 8 & NT & 11 & NT & NT & 100 & NT \\
\hline B. parabrevis IFO $12334^{\mathrm{T}}$ & 51.8 & 20 & NT & 16 & NT & NT & NT & 100 \\
\hline
\end{tabular}

${ }^{a}$ Abbreviations for culture collections: NRRL, Microbial Properties Research, National Center for Agricultural Utilization Research, Peoria, Ill.; ATCC, American Type Culture Collection, Rockville, Md.; JCM, Japan Collection of Microorganisms, Saitama, Japan; IFO, Institute for Fermentation, Osaka, Osaka, Japan.

${ }^{b} \mathrm{G}+\mathrm{C}$ contents are averages of the values from three determinations. The maximum variation observed was 0.2 mol\%.

${ }^{c}$ Reassociation values are the averages of the values from two determinations. The maximum variation observed was $8 \%$.

${ }^{d} \mathrm{~T}=$ type strain.

${ }^{e}$ NT, not tested.

${ }^{*}$ Corresponding author. Mailing address: Research Laboratory, Higeta Shoyu, Co., Ltd., 2-8 Chuo-cho, Choshi, Chiba 288, Japan. Phone: +81-479-22-1180. Fax: +81-479-24-3422. 
game, Calif.) in microplate wells and a fluorometric method described by Ezaki et al. (2).

The major menaquinone of the type strains of $B$. agri and B. centrosporus was menaquinone 7 (more than $99 \%$ of the total menaquinones), and these strains contained anteiso$\mathrm{C}_{15: 0}$ acid $(40 \%$ of the total cellular fatty acids in $B$. agri and $63 \%$ of the total cellular fatty acids in B. centrosporus) and iso- $\mathrm{C}_{15: 0}$ acid (41 and $23 \%$ of the total cellular fatty acids in $B$. agri and $B$. centrosporus, respectively). The extracellular proteins produced by the type strains of $B$. agri and $B$. centrosporus cross-reacted with the antiserum against protein HWP (data not shown). These results were almost the same as the results obtained for the other species belonging to the $B$. brevis group (5).

The DNA base compositions and levels of DNA relatedness of the strains tested are shown in Table 1 . The levels of DNA relatedness between the type strains of $B$. centrosponus, B. migulanus, B. choshinensis, and $B$. parabrevis were found to be low. Therefore, these taxa can be considered independent species. However, the DNA base compositions of the three strains of $B$. agri and two strains of $B$. galactophilus included in this study ranged from 52.1 to 53.2 mol\% $\mathrm{G}+\mathrm{C}$. These strains exhibited DNA relatedness values of more than $72 \%$. Therefore, these strains should be considered members of a single species on the basis of the criteria which were suggested by an ad hoc committee of the International Committee on Systematic Bacteriology (7). Since the name $B$. agri has nomenclatural priority over $B$. galactophilus according to the International Code of Nomenclature of Bacteria (3), B. galactophilus should be considered a later subjective synonym of $B$. agri. Therefore, we propose that the name Bacillus agri should be retained for this species; the type strain of this species is NRRL NRS-1219.
We thank L. K. Nakamura of the National Center for Agricultural Utilization Research, Agricultural Research Service, U.S. Department of Agriculture, for supplying some bacterial strains and Y. Sakaguchi for technical assistance.

\section{REFERENCES}

1. Ebisu, S., A. Tsuboi, H. Takagi, Y. Naruse, H. Yamagata, N. Tsukagoshi, and S. Udaka. 1991. Conserved structures of cell wall protein genes among protein-producing Bacillus brevis strains. J. Bacteriol. 172:1312-1320.

2. Ezaki, T., Y. Hashimoto, and E. Yabuuchi. 1989. Fluorometric deoxyribonucleic acid-deoxyribonucleic acid hybridization in microdilution wells as an alternative to membrane filter hybridization in which radioisotopes are used to determine genetic relatedness among bacterial strains. Int. J. Syst. Bacteriol. 39:224-229.

3. Lapage, S. P., P. H. A. Sneath, E. F. Lessel, V. B. D. Skerman, H. P. R. Seeliger, and W. A. Clark (ed.). 1992. International code of nomenclature of bacteria. 1990 revision. American Society for Microbiology, Washington, D.C.

4. Nakamura, L. K. 1993. DNA relatedness of Bacillus brevis Migula 1900 strains and proposal of Bacillus agri sp. nov., nom. rev., and Bacillus centrosporus sp. nov., nom. rev. Int. J. Syst. Bacteriol. 43:20-25.

5. Takagi, H., O. Shida, K. Kadowaki, K. Komagata, and S. Udaka. 1993. Characterization of Bacillus brevis with descriptions of Bacillus migulanus sp. nov., Bacillus choshinensis sp. nov., Bacillus parabrevis sp. nov., and Bacillus galactophilus sp. nov. Int. J. Syst. Bacteriol. 43:221-231.

6. Udaka, S. 1976. Screening for protein-producing bacteria. Agric. Biol. Chem. 40:523-528.

7. Wayne, L. G., D. J. Brenner, R. R. Colwell, P. A. D. Grimont, O. Kandler, M. I. Krichevsky, L. H. Moore, W. E. C. Moore, R. G. E. Murray, E. Stackebrandt, M. P. Starr, and H. G. Trüper. 1987. Report of the Ad Hoc Committee on Reconciliation of Approaches to Bacterial Systematics. Int. J. Syst. Bacteriol. 37:463-464. 